UDC 069(497.11 Beograd)

https://doi.org/10.18485/ms_zmslu.2021.49.16

Оригинални научни рад

Милена Б. Јокановић*

\title{
ЗГРАДА МУЗЕЈА КАО МУЗЕЈСКИ ПРЕДМЕТ: БИОГРАФИЈА МУЗЕЈА 25. МАЈ У БЕОГРАДУ
}

САЖЕТАК: Зграда Музеја 25. мај која се данас налази у оквиру комплекса Музеја Југославије у Београду, изграђена је као тотално уметничко дело, поклон за 7о-и рођендан председнику Федеративне Народне Републике Југославије Јосипу Брозу Титу, на улазу у његов резиденцијални комплекс. Положај и првобитна намена музејске зграде, значења која су уткана у ово дело, те промене које је претрпела услед турбулентних социокултурних и политичких околности и бројни догађаји којих је била протагониста, сугеришу да, иако се данас користи као изложбени простор Музеја, и ово здање само по себи има изузетан сведочанствени потенцијал. Ослањајући се на теорију музејског предмета с једне стране и на метод биографије ствари с друге, у раду се кроз различите контексте и функције прате промене вредности и значења зграде Музеја 25. мај у Београду од њеног настанка и показује се како се ова зграда данас може сагледати као још један од артефаката у колекцији поклона Јосипу Брозу Титу коју Музеј Југославије баштини.

КљУЧНЕ РЕЧИ: Музеј 25. мај, музеалија, контекст предмета, биографија ствари.

Полазећи од метода биографије ствари и дефинисања вредности предмета у музејском контексту, у овом раду сагледаћемо зграду Музеја 25. мај у Београду као својеврсну музеалију. Пратећи различите намене које је ова зграда имала од свог настанка у другој половини XX века све до данашњег функционисања у оквиру комплекса Музеја Југославије, препознаваћемо промене вредности и значења које она носи током веома разноликих социокултурних и политичких околности. Најзад, попут предмета који реконтекстуализован у музејски контекст губи своју примарну и добија документарну вредност и функцију, зграду Музеја 25. мај препознаћемо као део колекције Музеја Југославије који кроз кустоске интерпретације, програме и интервенције, данас открива значајан сведочанствени потенцијал.

\footnotetext{
* Универзитет у Београду, Филозофски факултет, milena.jokanovic@f.bg.ac.rs
} 


\section{Ка дефиницији музејског предмета}

Музејски предмет, односно предмет баштине, јесте онај објекат који је издвојен из своје реалности да би у новој музејској стварности у коју је пренесен био документ једног времена, обичаја, културе или подручја и свих система вредности које друштво у датој епохи заступа.

Овакав предмет, смештен у музејски контекст, у теорији музеологије често се назива музеалијом, односно предметом чија је улога промењена у односу на примарну; музеалија пренесена у музејску стварност бива реконтекстуализована, односно овај предмет више нема своју првобитну функцију, већ постаје носилац значења и информација у музејској стварности. Основна својства која предмет у музеју има јесу својства сведочанствености, односно документарности - сведочења о одређеној појави, времену чији је предмет репрезент (БулАтовић 2005: 11).

Размишљајући о човековом односу према предметима, Питер ван Менш предмете дели у три категорије: предмете који су у употреби, предмете у археолошком контексту и предмете у музеолошком контексту. Док је врло јасно да прву категорију представљају предмети који своју намену имају у свакодневном животу и да овде говоримо о примарној функцији предмета, а музеолошки контекст је управо она нова стварност објекта који измештен из „реалног” света бива уведен у музејске оквире, морамо се запитати шта је тачно археолошки контекст предмета. Менш исти објашњава као привремени или стални депозит одбачених предмета. Овај депозит може бити стабилан - уколико се ради о намерном похрањивању предмета - где аутор наводи као пример јеврејску културу похрањивања светих списа за које се верује да не смеју бити уништени. Такође, према оваквој класификацији постоји и нестабилан депозит у којем се временом нађу сви артефакти који бивају замењени напреднијим, новијим објектима, попут различитих техничких уређаја и сл. (ВАн Менш 2015: 17).

Размишљајући о музејском предмету, можемо се осврнути и на антрополошке студије и метод биографије ствари који заступају првенствено Игор Копитоф (КорутоғF 1986) и Ајрун Ападурај (APPADURAI 1986). Наиме, предмете који су саставни део друштва немогуће је раздвојити од човековог живота и тога како се човек опходи према њима. Управо зато антрополози, Копитоф, а затим и Ападурај, сугеришу неопход-

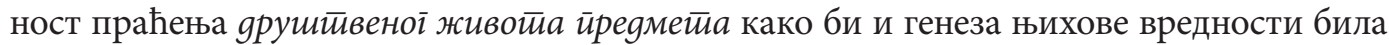
установљена. Игор Копитоф јасно објашњава да за различите културе и различите епохе различити предмети представљају слику актуелних система вредности, те сугерише метод биографије ствари и праћење живота предмета кроз време као метод којим се могу разумети и друштвене релације. Приликом креирања биографије ствари, поставили бисмо питања слична онима која постављамо о људима: шта су, социолошки, биографске могућности усађене у „статус” предмета и у време и културу и како се ове могућности реализују? Одакле долази ствар и ко ју је направио? Шта се до сада дешавало с том ствари и шта људи сматрају да би даље била њена идеална каријера? Шта су препознате „године” или периоди у „животу” ствари и шта су културни 
маркери овога? Како се употреба ствари временом мења, шта се дешава када она досегне крај своје корисности (функционалности)?

Пишући о приступу посматрања биографије ствари кроз призму археолошких, антрополошких и музеолошких истраживања, кустоскиња и музеолошкиња Марија Васиљевић закључује да

метафоре биографије заправо помажу да увидимо испреплетаност, саживот и везе људи и ствари у времену (и да данас те односе сазнамо/претпоставимо и саопштимо), јер ће свака биографија ствари бити везана за биографије људи, и обратно. Биографији ствари се може приступити у складу са феноменима које изучавамо. Тако антрополози Крис Годсен и Ивон Маршал из свог истраживачког искуства уочавају да извесни предмети у току свог живота акумулирају значења - постају вредни за појединца или заједницу због особе или догађаја са којима су до тада били повезани или се повезују. Тада сама биографија ствари постаје вредност предмета, на пример породични предмети који се наслеђују или пак ствари које уживају изузетно поштовање једне групе људи. (ВАСИЉЕВИТ 2013: 329).

Али, М. Васиљевић поставља питање: шта се дешава када тај исти предмет ступи у музеј?

Полазећи од горе објашњених полазишта, у даљем раду покушаћемо да зграду Музеја 25. мај, данас саставног објекта комплекса Музеја Југославије у Београду, сагледамо као својеврстан музејски предмет. Да бисмо у овоме истрајали, пратићемо биографију овог здања, односно све слојеве наслеђа које она директно открива, али и различите контексте кроз које ова зграда пролази као део музејске збирке Титових поклона, затим места које губи своју примарну функцију, те места које постаје музеализовано и представљено у оквиру Музеја Југославије као музеалија изузетног значаја.

\section{1. слој: зграда као тотално уметничко дело}

Зграду Музеја 25. мај пројектовао је архитекта Михаило Јанковић, који је својим богатим стваралачким опусом веома утицао на промењену визуру Београда након Другог светског рата. Одмах након завршетка факултета 1936. године, Јанковић је започео рад у војним пројектантским бироима, и након рата основао је сопствени атеље „Стадион” на чијем ће челу бити све до своје смрти 1976. године. Због веома значајних пројеката које ради, попут плана адаптације и довршења Палате Савезног извршног већа - пројекта који представља кључну прекретницу у његовој каријери (PUTNIK 2017: 353), затим зграде Централног комитета на Новом Београду, Спортског центра и стадиона Ташмајдан, стадиона Југословенске народне армије (данашњег „Партизановог” стадиона који је у непосредној близини и симболичкој вези са Музејем 25. мај), те многих других стамбених објеката, Јанковић је добио незваничну титулу „дворског архитекте” (Мишић 2011: 147-148). Стога не чуди да је изградња 


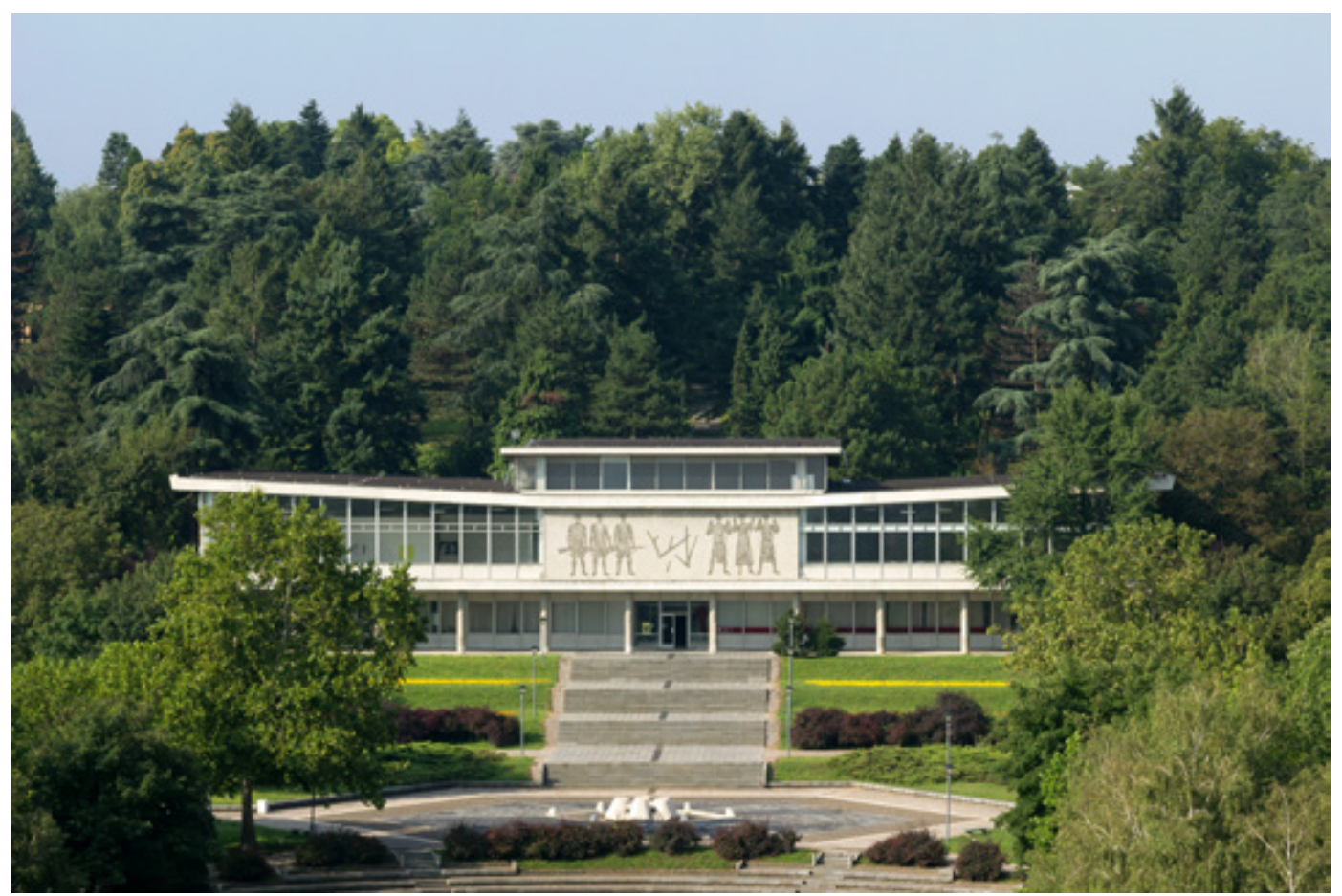

Сл. 1. Зграда Музеја 25. мај, екстеријер (фотографија Реље Иванића, Архив Музеја Југославије)

Музеја 25. мај, поклон града Београда за седамдесети рођендан председника Јосипа Броза Тита, поверена управо њему (сл. 1).

Ако се осврнемо на поменуто мењање визуре Београда након Другог светског рата и успостављања социјалистичке идеологије, објекат Музеја 25. мај може се посматрати као симбол оваквих стремљења. Појашњавајући системе легитимације моћи путем наслеђених и нових средстава у социјалистичкој Југославији, историчар архитектуре Александар Игњатовић тумачи генералну трансформацију Дедиња од елитног, резиденцијалног дела града у отворенији, простор доступан грађанству који је новоизграђеном Мостарском петљом (1967-1974) и железничком станицом „Прокоп” (1977) повезан и са историјским центром престонице и са Новим Београдом, најснажнијим симболом новог политичког поретка. „Дедиње је, попут Топчидера са којим га спајају бројни односи сличности и отклона, функционисало као важна симболичка представа у репрезентативној слици владара - династија Обреновић и Карађорђевић, као и Јосипа Броза Тита." Како Игњатовић објашњава, сви су они легитимисали своју моћ на сличној представи владаоца који је, као и његов резиденцијални и репрезентативни простор, истовремено у средишту и изван политичког дискурса, а простор Дедиња утврђен као „природни” део Београда, „једновремено изван и унутар 
града”, задобио је велики симболички потенцијал „да укаже на йрироgни хабитус владара који, у том простору (из)међу, фиксира своје обитавалиште. Управо је однос јединства између политичког (у традиционалном смислу 'теолошког') и демотског (тј. 'природног') у сржи читања простора Дедиња и Музеја 25. мај као симбола извора ауторитета власти и средства легитимације моћи”, нагласиће аутор. Дихотомија овог простора, која одговара поменутој дуалној легитимацији владара, између затвореног, владарског, резиденцијалног места и доступног, отвореног, прекомпонованог амбијента истицала се управо здањем Музеја 25. мај који стоји на іраници ова два, испред Титовог резиденцијалног комплекса. За време прославе Дана младости по којем Музеј носи име, ова зграда, али и стадион и околни паркови „постајали су места конструисања политичког националног тела и његовог јединства са политичким телом владаоца." (ИгњАТовић 2011: 609, 610).

Овај објекат замишљен као тотално уметничко дело, Gesamtkunstwerk односно синтеза архитектуре, сликарства и скулптуре, налазио се непосредно испред резиденцијалног комплекса друга председника, а са идејом да се управо овде излажу сви поклони које Броз добија током своје владавине, како од иностраних делегата тако и од свої нароga. Детаљније сагледавајући идеје уграђене у здање Музеја, можемо приметити да и оно, иако намењено да буде простор за излагање збирке поклона, и само представља део ове музејске збирке.

Збирка поклона Титу има карактер музеја као слике светиа (РАдић 2008). Она настаје почетком педесетих година прошлог века када пристиже највише поклона услед потребе да се додатно ојача култ личности Тита који је до раскида са Совјетским Савезом био у сенци Стаљиновог култа. Стога се доноси одлука о стварању званичног фонда. Различити дародавци од којих Броз добија најразличитије предмете током своје владавине, па и постхумно, условили су да збирка поклона јесте веома хетерогена целина коју њени кустоси уређују у односу на врсту предмета. Стога се овде препознају уметничка, етнографска, збирка фото-албума, археолошка, те збирка техничких предмета. Како кустоси Музеја Југославије истичу док размишљају о начинима интерпретације наслеђене збирке поклона, ово је фонд

у коме су заступљени предмети од изузетне материјалне и културно-историјске вредности до оних који се сврставају у категорију ефемерних, у уметничком смислу тривијалних или материјално безвредних, а који су, како то савремена музеолошка пракса показује, важни сведоци различитих времена и култура. Тито је заједнички именитељ свих предмета, али он је у самом процесу размене пасивизиран јер се поглед окреће од њега ка дару као репрезенту дародавца и до изражаја долазе обележја предмета кроз која се јавља глас онога који дарује. Тако се може рећи да је ова континуирана акумулација створила кабинет чуда Југославије (ЖивАНОВИЋ, ТОРОМАН 2016: 32).

Не случајно, ова збирка сагледана као својеврстан кабинет чудеса најразличитијих предмета са свих континената, од мноштва разноликих материјала и облика, који постављени у зачудним јукстапозицијама изазивају дивљење посматрача, 
захтевала је и адекватан простор за излагање како би Тито као суверен овог микрокосмоса у којем га је поштовао цео света и волео сваки члан југословенског друштва, могао да фасцинира посетиоце за живота, али и остане запамћен након смрти (ЈокАнОвиЋ 2018). У овом контексту, зграда Музеја 25. мај, и сама поклон Титу, представља један од предмета у фонду ове збирке чудеса која и својим значењима одговара идеји величања председника. Учествујући у одабиру места за зграду музеја поклона, испред резиденцијалног комплекса, Тито директно сугерише неопходност наглашавања јаког идентитета овог места и оваквим здањем, те се за исто расписује јавни конкурс. Како пише Томислав Марковић, по оцени расписивача конкурса, прилог Мике Јанковића је ближе одговарао пропозицијама конкурса од супротстављеног пројекта Драгише Брашована:

Ослањајући се на тековине наивноі симболизма предратног модернизма, креира хоризонталистички објекат напетих крила са корбизијански извајаном колонадом масивних стубова у приземљу, а лаким прозрачним и остакљеним корпусом с наративним мозаиком посред лица фасаде, на спрату (MARKOVIĆ 1976: 1404).

Тумачећи музејску зграду као објекат интернационалног стила, и историчарка архитектуре Владана Путник ће нагласити истовремену неоспорност политичке и социјалистичке реторике овог здања чији је главни елемент мозаик на централном панелу изнад улаза (РUTNIK 2017: 355) Наиме, поменути мозаик на фасади је дело Бошка Карановића и представља Народноослободилачку борбу и изградњу ратом разрушене земље и, налазећи се одмах изнад главног улаза у Музеј', сугерише почетак читања наратива који ће се унутар зграде наставити. Уласком, већ на централном ходнику првог спрата, посетилац се сусреће са импозантном, 64 квадратна метра великом фреском хрватског уметника Раула Голдонија чија је тема: „живот, страдања и борба народа на подручју краја председника Јосипа Броза Тита од средњег века до ослобођења", како стоји у првом члану Уговора између Секретаријата за просвету и културу Скупштине града Београда, као инвеститора, и аутора. ${ }^{2}$ Задата тема реализована је кроз приказ буне словенских сељака на простору Хрватског Загорја 1573. године, чији је вођа био Матија Губец, и Народноослободилачке борбе с друге стране. Наглашавајући реткост представљања историјских фигура које указују на радикално супротстављене идеологије, кустоскиња Музеја Југославије Ана Панић објашњава аналогије између Тита и Матије Гупца, вође сељачке буне у Хрватској у XVI веку. ${ }^{3}$ Управо ова фреска, вероватно због теме и начина њене реализације, видећемо,

\footnotetext{
${ }^{1}$ Овај мозаик и целокупну зграду замишљену као тотално уметничко дело, истакнути историчар уметности Лазар Трифуновић оштро ће критиковати (Трифуновић 1962).

2 Уговор између Секретаријата за просвету и културу Скупштине града Београда, као инвеститора, и Раула Голдонија, академског сликара, (1963), Архив Југославије, Канцеларија Маршала Југославије.

3 Кустоскиња Панић ће, прихватајући и став теоретичара културе и медија Драгана Ћаловића, закључити: „Ово повезивање требало је да подсети на сиромашно и сељачко порекло Јосипа Броза
} 


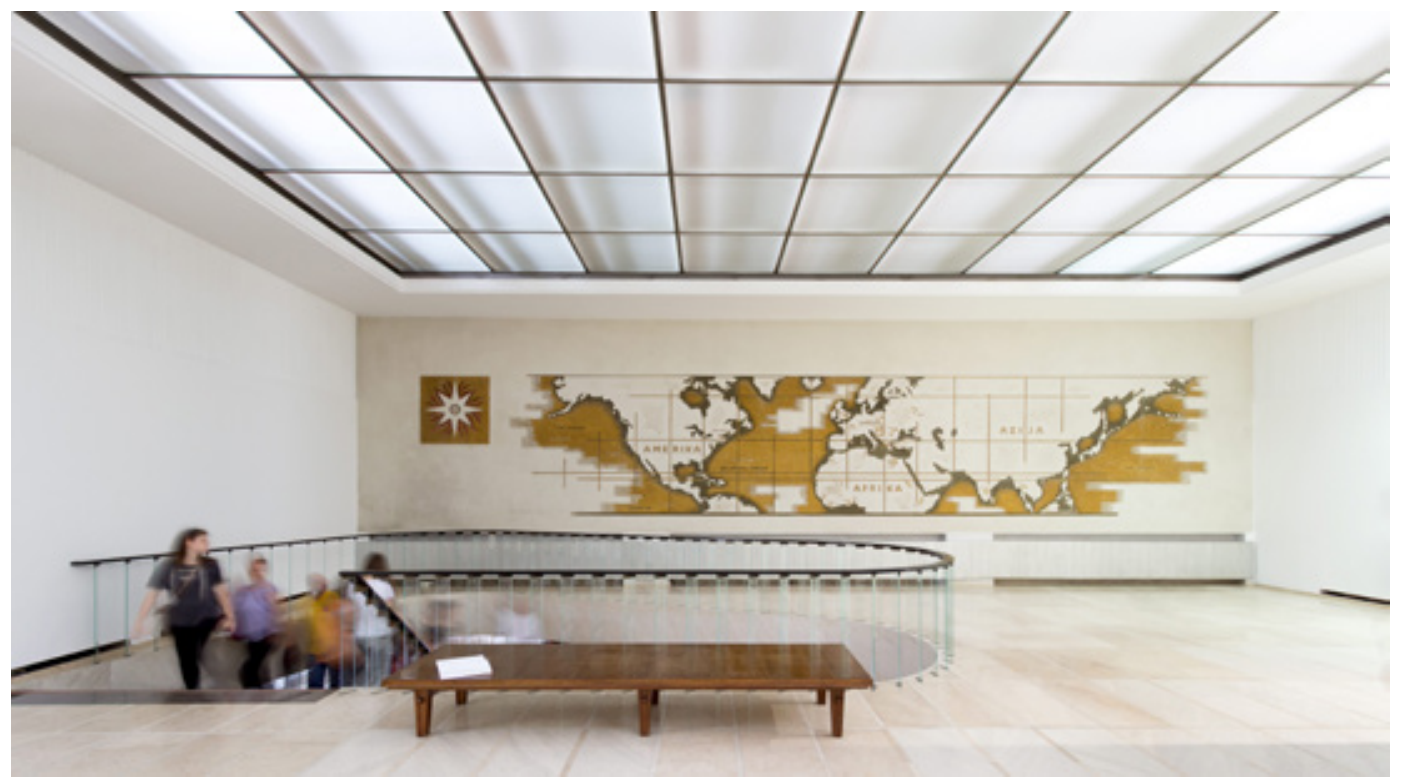

Сл. 2. Рељефна мапа света у ентеријеру Музеја 25. мај (фотографија Реље Иванића, Архив Музеја Југославије)

биће неподобна током деведесетих година, те протагониста промена у биографији зграде Музеја 25. мај.

Комуницирајући с Голдонијевом представом, на зиду преко пута налази се рељефна мапа света са обележеним „путем мира” којим Броз креће започињући оснивање Покрета несврстаних. Посматрана у контексту ове целине и дидактичке идеолошке улоге коју је Музеј имао, мапа треба да покаже континуитет борбе за људска права и потцрта Броза као борца за равноправност и мирољубиву коегзистенцију народа (сл. 2). Тако је председник, види се кроз декорацију ове зграде, тоталног уметничког дела, заслужио свој положај у земљи након што је водио њено ослобођење, положај потврђен и изразито позитивном перцепцијом овог државника у свету (ПАнић 2020).

Након свечаног отварања 25. маја 1962. године, у Музеју се, у складу са наративом уграђеним у здање, излажу у највећем броју штафете, макете и одабрани експонати из ликовне збирке који су могли имати „подстицајан, морални и политички, утицај на омладину” (РАдић 2008: 68), док су највреднији предмети остали у резиденцијалним просторима председника. Оваквом поставком требало је одговорити на оснивачки акт Музеја 25. мај који треба да „одражава личност и активности Јосипа Броза

који је као и Губец био народски вођа и од политички прогоњеног илегалца, преко лидера војног покрета, израстао у крупну политичку фигуру” (ПАнић 2020). 
Тита у стварању нове социјалистичке заједнице и представља средство за инспирисање различитих активности повезаних са истраживањем целог раздобља коме је обележје дао Тито."4

Након смрти Јосипа Броза, 1980. године, зграда Музеја 25. мај постаје саставни део Меморијалног центра Јосип Броз Тито (МЕмОРИЈАЛнИ цЕНТАР ЈосИП БРОЗ ТИТО 1991). Док овај комплекс Титових резиденцијалних здања, објеката у Парку скулптура и сам Музеј 25. мај функционишу као Меморијални центар, ова зграда - музејски предмет, задржава свој примарни контекст, те и даље представља величајност личности друга Тита својим изгледом и изложеном збирком.

\section{2. слој: зграда на изнајмљивање - археолошки контекст предмета}

Услед распада социјалистичке Југославије и конфликта деведесетих година, политике сећања и грађења јавног идентитета држава, до тада чланица Југославије, драстично се мењају. Стога се јавни споменици из времена владавине Јосипа Броза, називи улица, школа, као и курикулуми у оквиру званичних наставних програма када су историја и географија у питању - потпуно мењају враћајући се националним идеологијама и потискујући идеје братства и јединства јужнословенских народа. У оваквој атмосфери, зграда Музеја 25. мај постаје део нове целине. Наиме, као неподобна за то време, институција Меморијалног центра „Јосип Броз Тито” (како је резиденцијални комплекс Јосипа Броза заједно са зградом Музеја 25. мај и гробом овог председника у свом саставу носио назив од 1982. године) бива трансформисана у државне резиденције с једне стране и комплекс Музеја историје Југославије с друге. ${ }^{6}$ Тада парк скулптура, такозвани Стари музеј, затим Кућа цвећа улазе у састав овог

4 Оснивачки акт указује на то да је задатак сталне поставке да „одражава личност и активности Јосипа Броза Тита у стварању нове социјалистичке заједнице и представља средство за инспирисање различитих активности повезаних са истраживањем целог раздобља коме је обележје дао Тито” (Документација Музеја историје Југославије; Водич кроз Музеј „25. мај”, Београд 1978).

5 О политици преименовања улица и јавних институција вид.: СТОЈАновић 2009.

${ }^{6}$ Да би се пронашло решење за функционисање Меморијалног центра Јосип Броз Тито, Белог двора, Старог двора, Музеја 4. јула и Музеја Револуције народа и народности, влада Југославије је 1992. године формирала експертску групу (неки од чланова групе су били: Драгослав Срејовић, Дејан Медаковић, Војислав Ђурић, Бранко Петрановић, Ирина Суботић итд.). Ова експертска група проследила је влади предлог за будућу употребу и функцију наведених институција које су биле у државном власништву. Тада је наведено да Бели двор, Стари двор и Меморијални центар Јосип Броз Тито, заједно са свим њиховим збиркама и околним парковима, треба сачувати у целини и прогласити културно-историјским добром од изузетне вредности и значаја за Југославију. Предложена идеја била је да се Стари двор и Бели двор баве историјом Југославије од 1918. до 1941. године, док би друге институције требало да се споје и баве југословенском историјом након 1941. године обједињујући овако наслеђе у један велики Музеј историје Југославије са више објеката/павиљона. Ипак, под овим именом од 1996. године нашли су се само део простора и колекција дотадашњег Меморијалног центра Јосип Броз Тито, колекција Музеја Револуције и галеријски простор на Тргу Николе Пашића (данашњи Историјски музеј Србије). 
музејског комплекса. Објекат Музеја 25. мај тек је 2000. године Скупштина града предала на коришћење Музеју (РАNIĆ 2017). Ако прихватимо радикалне ставове с краја XIX века о музеју као некрополи, онда и сам назив Музеј историје Југославије из 1996. године док Југославија још постоји као територијално мања, али и даље држава под тим именом, можемо протумачити као синтагму која обележава простор и време „протеране” из јавног дискурса, проглашене „мртвим” попут других предмета смештених у музеје, где више немају своју употребну функцију већ су реконтекстуализовани и служе само да, организовани у овим институционалним оквирима, сведоче о прошлим временима.

У овом контексту и зграда Музеја 25. мај убрзо потпуно губи своју примарну функцију доприношења култу личности Јосипа Броза и постаје простор који због своје архитектонске допадљивости и функционалности служи као галерија на изнајмљивање, односно у којем се често организују студентске уметничке изложбе и Октобарски салони савремене уметности. Иако не мењајући свој спољашњи изглед, склањање колекције Титових поклона, али и прекривање фреске Раула Голдонија, те грађење зида испред ње, а затим и прекривање мапе на зиду преко пута - веома утиче на значење ове зграде. Ако је сагледамо као предмет у збирци поклона, онај чија је примарна функција да велича свог власника, можемо увидети да се од деведесетих година овај предмет измешта из свог примарног у археолошки контекст. Сматрајући идеје које она оличава превазиђеним, а теме представљене у овом синтетичком споменику неподобним, власти овај предмет у датом тренутку препуштају забораву не трудећи се да га сачувају у целости.

\section{3. слој: зграда за испраћај - прелазни контекст предмета}

Полазећи од теорије катастрофе, Мајкл Томпсон (ТHOMPSON 1979) успоставља такозвану теорију смећа (rubbish theory) у којој прави разлику у начинима на које предмети могу бити сагледани. Овај аутор човека и његов однос према материјалној култури управо ставља у средиште теорије. У савременој култури он препознаје две категорије: „прелазне” (transient) и „трајне” (durable) предмете. Како наводи, предмети из категорије прелазних временом губе на својој вредности, односно на значају за човека, те имају ограничен животни век. С друге стране, предмети који припадају категорији трајних временом добијају све већу вредност и, у идеалном случају, имају бесконачан животни век. Многе познате предмете баштине, те објекте који су припадали краљевима, као и оне израђене уз помоћ посебне виртуозности, аутор сврстава у категорију трајних. У оба случаја, искључиво начин на који се човек односи према стварима, сврстава исте у једну или у другу категорију. Наиме, када се ради о предметима, постоји веза између нашег погледа на свет и наших понашања у том свету, како Томпсон закључује. Ипак, за разлику од помињаних Копитофа и Ападураја који не дефинишу ниједно средишње стање између ова два супротстављена пола у категоризацији предмета, према Томпсону, свет предмета не исцрпљују само они прелазни 
и трајни, већ у овом свету он уочава и предмете такозване нулте, односно непроменљиве вредности које назива смећем и сврстава их у трећу категорију. Његова хипотеза је да је ова прикривена категорија смећа настала управо опадањем вредности прелазних објеката, те њиховим одбацивањем и прављењем ђубришта. У идеалном свету, сви предмети би када достигну ову нулту, безвредну тачку, постали прашина и заувек нестали, међутим, оно што се заправо дешава јесте да ови предмети настављају да постоје у такозваном ванвременском и безвредносном лимбу (који можемо препознати и као облик археолошког контекста предмета у музеолошкој теорији) из којег их некада касније открије неки креативни појединац и успешно преведе у категорију трајних предмета.

Уколико се сада вратимо здању Музеја 25. мај, онда бисмо претходно помињане промене у ентеријеру зграде, односно прекривање рељефа и фреско-сликарства које носи јасну идеолошку поруку, могли протумачити као одбацивање примарне функције ове зграде, препуштање предмета забораву. С друге стране, прва деценија двехиљадитих година ће у биографији овог здања ипак открити изузетан симболички потенцијал, услед којег ће иста, закључићемо, тих година бити у прелазној фази, ка креирању музеалије, предмета трајне вредности.

Док бројна савремена уметничка дела која се тих година у оквиру Октобарских салона излажу баш у Музеју 25. мај као сајт специфик инсталације, сугеришу још увек присутну симболичност зграде као простора који слави култ личности владара, догађај који се може уврстити у новију политичку историју, а који посебно наглашава свест друштва о положају и значењу здања и самог места на ком се налази, свакако јесте излагање мртвог тела бившег председника Савезне Републике Југославије Слободана Милошевића у згради Музеја 25. мај. Наводећи различите потенцијалне разлоге који су довели до тога да се овај бивши председник јавно оплакује управо у оквиру овог здања, а пре сахране испред његовог породичног дома у Пожаревцу, Олга Манојловић Пинтар и Александар Игњатовић веома вешто изводе и следећи закључак:

Ипак, најинтригантнији аспект такве необичне одлуке била је перцепција самог Музеја у јавности. Ова институција је замишљена као један од централних и монументалних наратива социјалистичке југословенске историје. Током комунистичке ере функционисао је као истакнуто место ходочашћа за многе Југословене. Од 1991. године Музеј је постепено препуштан забораву и његов првобитни значај је нашироко игнорисан. Дакле, феномен излагања Милошевићевог леша у Музеју могао би се схватити као одређени облик званичног раскида како са социјализмом, тако и са Југославијом. [...] као последњи симбол социјализма и Југославије [...], Милошевић је коначно и дословно постао артефакт изложен у музеју посвећеном социјалистичкој Југославији (MANOJLOVIĆ PINTAR, IGNJATOVIĆ 2011: 786; превод Милена Јокановић).

Ови аутори нагласиће и значај положаја Музеја на Топчидерском брду, месту које се током читавог југословенског периода везује за владаре - краљеве и председнике којима су овде резиденције - и носи јак симболички потенцијал. Најзад, видећемо, 
након овог догађаја, а радом кустоса (које можемо повезати са креативним појединцима из Томпсонове теорије) и сама зграда Музеја 25. мај постаје артефакт, музејски предмет који ће, реконтекстуализован у односу на првобитну функцију, досегнути сведочанствени потенцијал и постати својеврсна музеалија у оквиру шире колекције Музеја (историје) Југославије.

\section{4. слој: зграда као музеалија - музеолошки контекст предмета}

Друга деценија XXI века доноси веће интересовање за југословенско социјалистичко наслеђе у областима друштвених и хуманистичких наука, те се све чешће говори и о потреби за свеобухватним југословенским студијама (вид.: ЕRDEI и др. 2019). У овој деценији видно се мења и функционисање Музеја (историје) Југославије који временом све посвећеније приступа одговарању на име које му је деведесетих година дато, односно спровођењу у дело мисије и визије записаних у музејски статут. Кустоси Катарина Живановић и Татомир Тороман наводе

До заокрета у раду Музеја (историје) Југославије дошло је у другој деценији његовог постојања. Значајне промене у овом периоду условљене су препознавањем ширих потенцијала институције, постављањем искусног менаџмента, укључивањем стручњака упознатих са савременим музеолошким теоријама и новим тенденцијама у рад музеја, као и са порастом интересовања истраживача и публике за југословенско наслеђе. Ова деценија у раду $\mathrm{M}(И)$ Ј представља период ауторефлексије, отварања нових тема, смелих експеримената и редефинисања улоге музеја у друштву (ŽIVANOVIĆ, TOROMAN 2016).

Тежећи да југословенско наслеђе сагледају кроз различите феномене, а не нужно хронолошки, запослени најзад 2016. године успевају и у преименовању ове институције, те мењању идентитета који иста комуницира јавности (JOKANOVIĆ 2013). Наш протагониста, зграда Музеја 25. мај од тада је у саставу Музеја Југославије, а бројни програми и изложбе, те најзад и реконструкција и потпуно враћање оригиналног изгледа овог здања, указују на то да се исто може тумачити као својеврсни музејски предмет, део колекције који има богати сведочанствени потенцијал.

Године 2011. помињан рељеф „мапа Титовог пута мира” на првом спрату зграде који је био прекривен гипсаним зидом због потреба изложбених активности, коначно је откривен. Неколико година касније откривена је и Голдонијева фреска на наспрамном зиду, до тада прекривена платном због потреба изложбених активности на Октобарском салону савремене уметности, а заправо сматрана неподобном у време које смо у биографији зграде Музеја 25. мај означили као одбацивање, стварање смећа од предмета - а затим је зид који се налазио испред ње 2015. године срушен након великих радова на конзервацији и рестаурацији ове веома оштећене представе. Поводом четрдесетогодишњице од смрти архитекте Михаила Мише Јанковића, у Музеју Југославије се отвара изложба „Препознавање” којом се јавно представљају (поново истичу) вредности зграде Музеја 25. мај, док запослени, стручњаци у области 


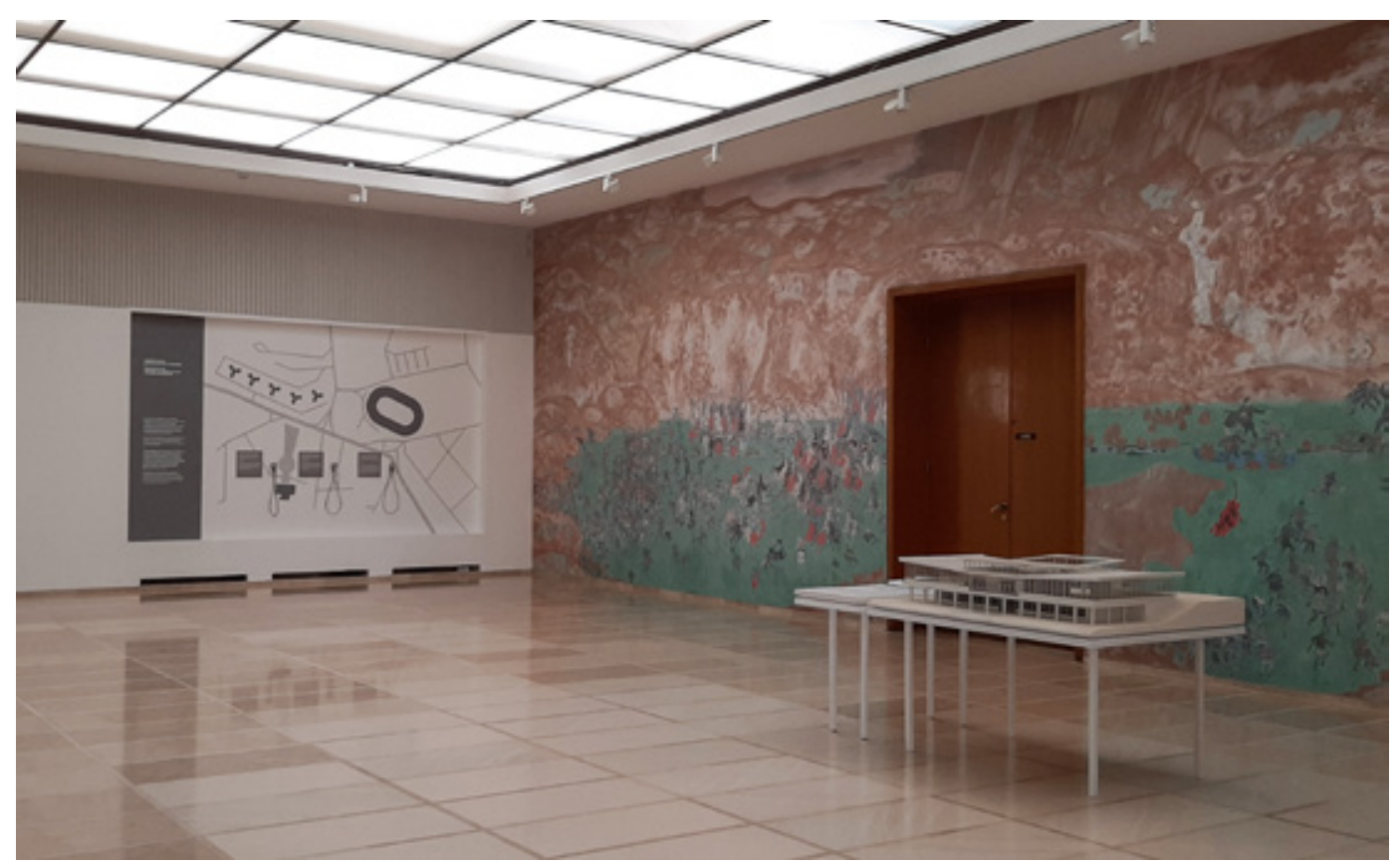

Сл. 3. Тренутни изглед ентеријера Музеја 25. мај, централни хол на првом спрату са обновљеном фреском Раула Голдонија и делом изложбе „Препознавање” - макетом и звучном мапом зграде Музеја 25. мај (фотографија Милене Јокановић)

архитектуре и уметности, те станари из околних солитера у оквиру пратећих програма говоре о значењу зграде и околине за њих, „а посетиоци могу да погледају и додирну макету Музеја, специјално направљену овим поводом” (сл. 3). Као последица изложбе настају и вођене туре којих су ова зграда и њен архитекта протагонисти, а улица која води до улаза у Музеј Југославије исте године је преименована и до данас носи назив Улица Михаила Јанковића. Сви ови подаци говоре у прилог томе да се интерпретацијом наслеђа Музеја 25. мај овом објекту враћа вредност, односно ствара нова, те се он сагледава као музеалија изузетног значаја. Како би прешао из нултог, археолошког контекста у предмет трајне, музеолошке вредности, овом споменику архитектуре ентеријер је недавно и реконструисан, док се музејски менаџмент залаже за реконструкцију фасаде у блиској будућности.

Изложба отворена одмах након реконструкције објекта ма становништва услед конфликта деведесетих година, турбулентног периода који, видели смо, утиче и на живот̄ ове зграде, најављује ипак да ће Музеј 25. мај постати

7 Изложбом кустоскиња Симоне Огњановић и Ане Панић „Деведесете: речник миграција”, отвореном децембра 2019. године у згради Музеја 25. мај, у Музеју Југославије се први пут у оквиру изложбеног 
много више од музеалије, те да ће $\bar{u} е \bar{u} u$ слој у биографији овог атрактивног излагачког простора, заједно са целокупним комплексом Музеја Југославије, означавати форум за размену мишљења и нове интерпретације југословенског наслеђа.

„На крају, све што је вредно биће уметничко дело и post-festum.”

(Михаило Јанковић)

\section{ЛИТЕРАТУРА}

Appadurai, Ajrun. "Introduction: Commodities and the Politics of Value." In: Appadurai, Ajrun (ed.). The Social Life of Things. Commodities in Cultural Perspective. Cambridge: Cambridge University Press, 1986, 3-64.

БулАтовић, Драган. „Баштинство или о незаборављању.” Крушевачки зборник (BulAtović, Dragan. „Baštinstvo ili o nezaboravljanju.” Kruševački zbornik) 11 (2005): 7-20.

BAH МЕНШ, Питер. Ка мет̄оgолоіији музеолоіије. Београд: Музеј науке и технике (VAN MENš, Piter. Ka metodologiji muzeologije. Beograd: Muzej nauke i tehnike), 2015.

ВАСИљЕВИЋ, Марија. „Биографија ствари.” У: Музеолоїија, нова музеолоіија, наука о башитини. Београд: Центар за музеологију и херитологију (VASILJEVIĆ, Marija. „Biografija stvari.” U: Muzeologija, nova muzeologija, nauka o baštini. Beograd: Centar za muzeologiju i heritologiju), 2013, 325-334.

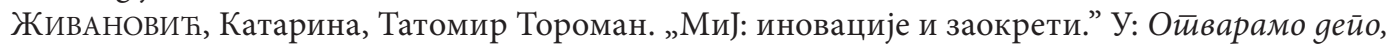
пројекат у оквиру рада на сталној поставци. Београд: Музеј Југославије (ŽIVANOVIĆ, Katarina, Tatomir Toroman. „MiJ: inovacije i zaokreti.” U: Otvaramo depo, projekat u okviru rada na stalnoj postavci. Beograd: Muzej Jugoslavije), 2016. <https://www.muzej-jugoslavije.org/ mij-inovacije-i-zaokreti> maja 2020.

ERDEI, Ildiko, Branislav Dimitrijević, Tatomir Toroman (ur.). Jugoslavija zašto i kako?. Beograd: Muzej Jugoslavije, 2019.

ИгњАТОВИЋ, Александар. „Отварање и популаризација: Музеј 25. мај и трансформација про-

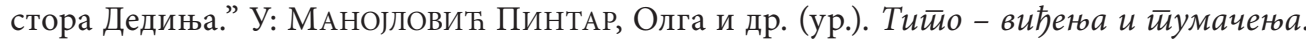
Београд: Институт за новију историју Србије - Архив Југославије (IGNJATOVIĆ, Aleksandar. „Otvaranje i popularizacija: Muzej 25. maj i transformacija prostora Dedinja.” U: MANOJLOVIĆ PINTAR, Olga i dr. (ur.). Tito - viđenja i tumačenja. Beograd: Institut za noviju istoriju Srbije - Arhiv Jugoslavije), 2011, 601-614.

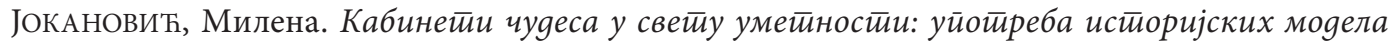
колекционирағь у савременој уметиничкој йракси, докторска дисертација одбрањена на Одељењу за историју уметности Филозофског факултета, Универзитет у Београду (JоKANOVIĆ, Milena, Kabineti čudesa u svetu umetnosti: upotreba istorijskih modela kolekcioniranja u savremenoj umetničkoj praksi, doktorska disertacija odbranjena na Odeljenju za istoriju umetnosti Filozofskog fakulteta, Univerzitet u Beogradu), 2018.

програма отварају питања о периоду распада Југославије деведесетих година, што представља велики искорак у дотадашњој пракси ове институције. 
JOKANOVIĆ, Milena. "Economy of Museum Image: Muzealisation of Yugoslavia." In: Cultures of Economies in Southeast Europe. Sarajevo: May 2013. DAAD network "Media and Memory", Universitat Konstanz, CRCEES, University of Sarajevo.

MANOJlOviĆ PinTAR, Olga, Aleksandar Ignjatović. "National Museums in Serbia: A Story of Intertwined Identities." In: Building National Museums in Europe 1750-2010. Conference proceedings from EuNaMus, European National Museums: Identity Politics, the Uses of the Past and the European Citizen, Bologna 28-30 April 2011. Peter Aronsson \& Gabriella Elgenius (eds) EuNaMus Report No 1. Published by Linköping University Electronic Press. <http:// www.ep.liu.se/ecp_home/index.en.aspx?issue $=064>$, pp. 779-815.

MARKović, Tomislav. In Memoriam: Mihailo Mika Janković - „dvorski arhitekta” bez partijske knjižice, (1911, Beograd - 1976, Beograd). Beograd: Muzej Jugoslavije, 1976.

МЕМОРИЈАЛНИ ЦЕНТАР ЈОСИП БРОЗ ТИТО. Пр. Слободанка АСТ. Београд: Меморијални центар Jocип Броз Тито (Memorijalni centar Josip Broz Tito. Pr. Slobodanka AST. Beograd: Memorijalni centar Josip Broz Tito), 1991.

Мишић, Биљана. „Палата Савезног извршног већа у Новом Београду.” У: Наслеђе. Београд: Завод за заштиту споменика културе града Београда (MIšı́́, Biljana. „Palata Saveznog izvršnog veća u Novom Beogradu.” U: Nasleđe. Beograd: Zavod za zaštitu spomenika kulture grada Beograda), 2011, 129-150.

KopyTOFF, Igor. "The Cultural Biography of Things: Comoditization as Process." In: APPADURAI, Ajrun (ed.). The Social Life of Things. Commodities in Cultural Perspective. Cambridge: Cambridge University Press, 1986.

ПАнић, Ана. „Југословенско културно наслеђе: симболи, комеморација и контекст кроз случај Музеја историје Југославије (PANIĆ, Ana. „Jugoslovensko kulturno nasleđe: simboli, komemoracija i kontekst kroz slučaj Muzeja istorije Jugoslavije). <https://www.academia.edu/ 2972344/Jugoslovensko_kulturno_nasle\%C4\%91e_simboli_komemoracija_i_kontekst_kroz_ slu\%C4\%8Daj_Muzeja_istorije_Jugoslavije> марта 2020.

PANIĆ, Ana. „Holistički pristup u evaluaciji projekta Novi Stari Muzej ili kako učiti na sopstvenim uspesima i greškama." Zbornik radova Historijskog muzeja Bosne i Hercegovine (2017).

PUTNIK, Vladana. "From Socialist Realism to Socialist Aestheticism: Three Contrasting Examples of State Architects in Yugoslavia." In: PREDA, Caterina (ed.). The State Artist in Romania and Eastern Europe. The Role of the Creative Unions. Bucharest: Faculty of Political Science, University of Bucharest, 2017, 347-373.

РАдић, Ненад. „Слика Младост, краљица живота у контексту збирке Јосипа Броза Тита.” 3бор-

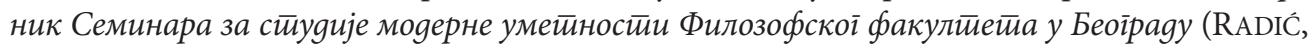
Nenad. „Slika Mladost, kraljica života u kontekstu zbirke Josipa Broza Tita.” Zbornik Seminara za studije moderne umetnosti Filozofskog fakulteta u Beogradu) III/IV (2008).

РАдић, Ненад. Збирка Јосийа Броза Тийа као слика моћи, необјављена докторска дисертација, одбрањена на Филозофском факултету, Универзитет у Београду (RADIĆ, Nenad. Zbirka Josipa Broza Tita kao slika moći, neobjavljena doktorska disertacija, odbranjena na Filozofskom fakultetu, Univerzitet u Beogradu), 2008.

СтолАновић, Дубравка. Калgрма и асфалй: урбанизачија и евройеизаиија Беоіраgа 1890-1914. Београд: Удружење за друштвену историју - Чигоја штампа (STOJANOVIĆ, Dubravka. Kaldrma i asfalt: urbanizacija i evropeizacija Beograda 189o-1914. Beograd: Udruženje za društvenu istoriju - Čigoja štampa), 2009. 
Трифуновић, Лазар. „Поводом радова у јавним зградама. Синтеза - шта је то?” Данас (TRIFUNOVIĆ, Lazar. „Povodom radova u javnim zgradama. Sinteza - šta je to?” Danas) (04. 07. 1962).

Thompson, Michael. Rubbish Theory: the Creation and Destruction of Value. Oxford: Oxford University Press, 1979.

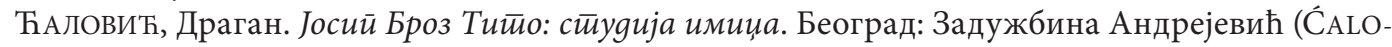
VIĆ, Dragan. Josip Broz Tito: studija imidža. Beograd: Zadužbina Andrejević), 2006.

\author{
Milena B. Jokanović \\ MUSEUM BUILDING AS A MUSEUM OBJECT - \\ BIOGRAPHY OF THE $25^{\text {th }}$ MAY MUSEUM IN BELGRADE
}

\title{
Summary
}

The building of the $25^{\text {th }}$ May Museum, today located within the complex of the Museum of Yugoslavia in Belgrade, was created as a work of art, a gift to the President of the Federal People's Republic of Yugoslavia, Josip Broz Tito for his $70^{\text {th }}$ birthday, leading to his residential complex. The very position and original purpose of the museum building, the meanings woven into this work, and the changes it underwent due to turbulent socio-cultural and political circumstances, as well as numerous events that have taken place here, suggest that this building has a remarkable testimonial potential although used today as an exhibition space. Relying on the theory of the museum object on one hand and the method of biography of things on the other, this paper follows the changes in the value and significance of the $25^{\text {th }}$ May Museum in Belgrade due to changes in the context and its functions. Finally, it is shown that this edifice itself can be observed today as one of the artifacts in the collection of gifts to Josip Broz Tito, preserved and interpreted in the Museum of Yugoslavia.

Keywords: $25^{\text {th }}$ May Museum, museum object, context, biography of things. 